\title{
The distribution of shallow marine fishes of the Kimberley, Western Australia, based on a long-term dataset and multiple methods
}

\author{
G.I. Moore ${ }^{1,2^{*}}$, S.M. Morrison ${ }^{1}$ and J.W. Johnson ${ }^{3}$ \\ 1 Department of Aquatic Zoology, Western Australian Museum, Locked Bag 49, Welshpool DC, \\ Western Australia 6986, Australia. \\ 2 School of Biological Sciences, University of Western Australia, Nedlands, Western Australia 6907, \\ Australia. \\ ${ }^{3}$ Ichthyology, Queensland Museum, PO Box 3300, South Brisbane, Queensland 4101, Australia. \\ * Corresponding author: glenn.moore@museum.wa.gov.au
}

\begin{abstract}
The Kimberley and offshore marine waters of Western Australia are some of the least impacted environments in the world. The region is facing increasing pressure from anthropogenic stressors and there is a need to understand the baseline faunal communities. Fish surveys were conducted between 2009 and 2014, using a variety of methods, including UVC and extractive techniques. The results of these contemporary surveys were added to all known shallow water fish records from more than 100 years of historical museum databases. We present the first comprehensive species by site table, based on nearly 15,000 species records to summarise species presence at more than 134 unique locations across the Kimberley marine region and highlight new distributional records. This reference dataset of 1,529 species should inform managers and assist the development of representative marine protected areas.
\end{abstract}

KEYWORDS: biodiversity, museum, collections, UVC, inventory

\section{INTRODUCTION}

Most tropical marine ecosystems are already substantially impacted by human activities (Pyke and Ehrlich 2010) and all are facing increasing threats from anthropogenic pressures such as pollution, overfishing or global warming along with severe natural disturbances such as cyclones (Pauly 1995; Knowlton and Jackson 2008). Accurate species inventories can provide baseline data to monitor the effects of many of these concerns (e.g. Perry et al. 2005; Vergés et al. 2014). Furthermore, as one of the most fundamental components of biodiversity science, accurate species inventories reveal regional taxonomic breadth and define species distributions, uncovering patterns of community composition, hotspots, endemism and are central to broader issues of evolution, ecology and management (e.g. Hutchins 2001; Pyke and Ehrlich 2010; Briggs and Bowen 2013; Gaither and Rocha 2013).

Species inventories are often fit-for-purpose and methodological compromises must be made.
Most monitoring surveys are necessarily based on carefully standardised, statistically rigorous methods that reduce bias. Such approaches may provide a robust assessment of a subset of the total fish community (Samoilys and Carlos 2000; Usseglio 2015; Caldwell et al. 2016); however, such surveys rarely attempt to include cryptic or small species and often do not (or cannot) discriminate between morphologically similar species (SmithVaniz et al. 2006; Holmes et al. 2013), and are seldom conducted by taxonomic specialists. As a result most ecological methods, such as Underwater Visual Census (UVC) or Baited Remote Underwater Video System (BRUVS), will considerably underdetect, and hence under-estimate total biodiversity (e.g. Plaisance et al. 2011; Usseglio 2015). In contrast, ad hoc collections and observations compiled using multiple methods, over a long timeframe, and with confirmed voucher specimens often provide a more thorough species list. With cryptic, rare and extra-limital records specifically targeted, and identifications made by specialist taxonomists, such inventories can be among the most complete 
(e.g. Johnson 2010; Larson et al. 2013; Moore et al. 2014; Roberts et al. 2019); however, data are usually collected in such a way that is difficult to use with the quantitative rigour demanded in most ecological studies (Caldwell et al. 2016).

Museums and other collection-based natural history research agencies are uniquely placed to provide the most comprehensive species inventories, employing dedicated taxonomists with honed identification skills backed by extensive collections of verifiable voucher specimens collected over many decades and by a diversity of methods. The importance of such taxonomic precision is often overlooked (Bortolus 2008). In an attempt to compile a 'complete' species inventory, Moore et al. (2014) summarised historical museum records (vouchers and observations between 1880 and 2009) of shallow water marine fishes from the Kimberley, north-western Australia and reported that 1,475 species were currently confirmed from shallow $(<30 \mathrm{~m})$ inshore and offshore reefs of the region.

The Kimberley and offshore areas comprise a vast expanse of remote marine environments with an incredible diversity of habitats and associated faunas (Wilson 2013; Wilson 2014; Jones et al. 2017). Inshore fringing reefs in the region are subject to enormous tides $(>11 \mathrm{~m})$, high turbidity and relatively low wave energy (DEC 2009; Wilson 2014). In contrast, the offshore reefs of submerged midshelf shoals and continental edge atolls of the region are typical Indo-west Pacific coral reef environments of relatively clear water and low productivity, and subject to seasonal cyclonic activity (Wilson 2013).

The shallow water reefs of the Kimberley are among the least impacted in the world by virtue of their remote location and low human population density (Halpern et al. 2008). Despite this, the region has a history of traditional, recreational and commercial fishing (Nowara and Newman 1996; Fox 1998; Molony et al. 2011), oil and gas exploration and extraction (Moore et al. 2016) and is increasingly affected by rising sea temperatures and coral bleaching (Ceccarelli et al. 2011; Gilmour et al. 2013; Le Nohaïc et al. 2017; Richards et al. 2019). Parts of the Kimberley marine region have been designated as marine protected areas for decades (e.g. Rowley Shoals), several years (e.g. Camden Sound) or are soon to be (e.g. Buccaneer Archipelago). Furthermore, since 2011 inshore areas of the region have been progressively designated as Indigenous Protected Areas recognising traditional custodianship of Sea Country and supporting joint management of environmental, biodiversity and cultural values (Kimberley Land Council 2019). Despite the known biological significance of the region, including decades of research, the marine flora and fauna of the Kimberley is still inadequately documented; largely due to the vast area, remoteness and environmental challenges of working there.

Here we report on six years of baseline marine surveys in the Kimberley between 2009 and 2014, which builds on a list of shallow water fish records from more than 100 years of historical records (Moore et al. 2014). We provide a comprehensive summary of known species presence at more than 134 unique locations across the Kimberley marine region and highlight new distributional records. This reference dataset should inform managers and assist the development of representative marine protected areas.

\section{MATERIAL AND METHODS}

Shallow water $(<30 \mathrm{~m})$ fishes were sampled with other phyla as part of the Western Australian Museum's (WAM) Kimberley Woodside Collection Project. Briefly, the 2009-2014 study area included reefs and islands near Cape Leveque in the south to Long Reef in the north and out to the continental edge atolls of the Rowley Shoals in the south, to Ashmore and Hibernia reefs in the north (see Bryce et al. 2018). The recent surveys included six 'Island Groups': three inshore (Buccaneer and Bonaparte archipelagos, Cassini Island/Long Reef), two offshore (Rowley Shoals and Ashmore/ Hibernia reefs) and a series of midshelf reefs and shoals (Table 1, S1). Full details of the project and recent study sites were provided by Bryce et al. (2017) and Richards et al. (2018).

Fishes were recorded by several methods:

Subtidal. Underwater Visual Census (UVC) was the main method of survey, where fish were counted by two independent, experienced observers [SM \& JJ at Adele Island and Montgomery Reef; GM \& SM at all other locations] on SCUBA or snorkel over a 60 minute period, during which the divers swam from deep (maximum of $20 \mathrm{~m}$ ) to shallow at each station. All fish within a $10 \mathrm{~m}$ wide belt were counted and some effort was allocated to including cryptic species during and after the time period. Counts were progressively recorded onto underwater slates and the quantitative analysis of these data will be presented elsewhere (Moore et al. in prep.). Where identification was uncertain, specimens were either collected (by hand, net or clove oil) or photographed for later confirmation. All species recorded beyond the transect belt or time period were also noted.

Intertidal. Intertidal stations were sampled using the ichthyocide rotenone in contained pools at 
low tide. The dimensions and depths of the pools varied considerably depending on the geological structure of each reef, but sampling areas were usually in the order of 20-50 $\mathrm{m}^{2}$. Pools were attended for at least one hour and all fishes were collected using hand nets. All specimens were later sorted on board the vessel and substantial voucher collections were retained and accessioned into the WAM fish collection.

Opportunistic. Additional species records were obtained by a variety of opportunistic methods. Angling was utilised sporadically, and other incidental sightings included landing on the deck (e.g. Hemiramphidae), dipnet from boat at night (e.g. Clupeidae), observed from the vessel (e.g. Mobula) or via substrate sampling for other invertebrate phyla (especially Gobiidae).

Identification of vouchered specimens and visual records were made by the authors, with input from other experienced ichthyologists with specific expertise. A conservative quality assessment process was followed whereby only those records identified with high confidence in the opinion of the authors were retained. All retained vouchers and photographs were identified in the laboratory, using available literature and comparison with specimens in museum collections. Currently accepted names generally follow the Australian Faunal Directory (ABRS 2019) with some decisions from Fricke et al. (2019). These recent records were added to a revised historical dataset of Kimberley marine fish fauna (summarised in Moore et al. 2014). The revisions to the data of Moore et al. (2014) reflect, inter alia, recent reidentifications, nomenclatural changes, improved knowledge and newly described species as well as incorporating additional data (Done et al. 1994; Fromont et al. 2012; Moore unpublished data). These combined data sources are presented as the first comprehensive species by site table for the Kimberley marine fishes.

\section{RESULTS}

\section{RECENT SURVEYS}

As part of the Woodside Collection project, the recent fish surveys included 174 survey stations at 37 islands/reefs across six Island Groups (Appendix 1; also Bryce et al. 2018). This included 124 UVC and 50 intertidal fish collections with many additional opportunistic observations and collections (see Methods). Some reefs were surveyed multiple times, others only once (Bryce et al. 2018). The recent dataset comprises more than 6,800 species records including more than 5,800 vouchered specimens permanently accessioned into the WAM collection. Additional unpublished UVC and collections by the senior author around the Sunday Islands and Bonaparte Archipelago between 2014 and 2016 were also included in Appendix 1.

After quality assessment to remove tentatively or unidentified species, the recent surveys recorded 840 taxa, most of which have been identified to species (Table 1, S1). Hundreds of tentatively identified records were removed pending further research. However, 10 taxa identified only to genus or family were retained, either because no other representatives of that genus were recorded (e.g. Rhynchobatus sp.), the taxonomy of the group is known to be unresolved (e.g. many gobies) or identification is especially difficult (e.g. female Bythidae). We felt that there was value in including these incompletely identified records to the species by site table to note their presence and encourage further research interest.

The taxa recorded during the recent surveys represent 79 families, with the most speciose being Labridae (98 spp.), Gobiidae (86 spp.) and Pomacentridae (84 spp.) (Appendix 1). The species most widely recorded (not the most abundant) were Labroides dimidiatus (32 islands), Acanthurus grammoptilus (30 islands), Thalassoma lunare (30 islands), Scarus schlegeli (29 islands) and Pomacanthus sexstriatus (28 islands) (Appendix 1). Nearly $30 \%$ of taxa were only recorded using extractive collecting methods (clove oil, rotenone, angling, netting, etc.) and not detected by UVC (data not presented).

In general, species richness increased with decreasing latitude and distance from mainland Australia (Table 1). An average of 94 and 82 species were recorded at reefs within the Buccaneer and Bonaparte archipelagos in the southern and central Kimberley, respectively. The northern Kimberley reefs around Cassini Island and Long Reef supported an average of 207 species. The mid-shelf reefs averaged 107 species, while the Rowley Shoals averaged 315 species and Ashmore and Hibernia reefs averaged 337 species.

\section{REVISED FULL KIMBERLEY DATASET}

Following a similar quality filtering process, the full dataset now includes a total of 1,529 shallow water marine fish taxa from the Kimberley region based on nearly 15,000 species records (Appendix 1), which represents an increase of more than 50 species to the whole Kimberley over the most 
recent species inventory (Moore et al. 2014; Table 2). New records of species were made at every recently surveyed island/reef, ranging from 11 new records from Wildcat Reefs in the Bonaparte Archipelago to 219 new records from the midshelf Browse Island (Table 1). Fourteen of these reefs were surveyed for the first time (although a single historic opportunistic record was known from both Albert Reef and Browse Island; Table 1). Substantial additional species records were added by the recent surveys at the level of Island Group, especially inshore (108-132 species added) and midshelf (273 species added) (Table 1$)$. The new species records are generally dispersed across the fish phylogeny although a quarter to a third of additions at each Island Group were cryptobenthic species (Appendix 1).

There are likely ten new species records for Western Australia, six of which are new species records for Australia (Table 2; but see Discussion). Four new species have been described, either directly or indirectly from specimens collected during this project: Pseudopataecus carnatobarbatus Johnson, 2012; Plectorhinchus caeruleonothus Johnson and Worthington Wilmer, 2015; Neopomacentrus aktites Allen, Moore and Allen, 2017; Scolopsis meridiana Nakamura, Russell, Moore and Motomura, 2018.

TABLE 1 Summary of fish species richness at recently surveyed islands and reefs in the Kimberley indicating historic (pre-2009) and recent (2009-2016) surveys.

\begin{tabular}{lllll} 
& Historic & Recent & Total & Recent Additions \\
\hline $\begin{array}{llll}\text { Buccaneer Archipelago } \\
\text { Cygnet Bay/Sunday Islands }\end{array}$ & 138 & & & \\
Brue Reef & 0 & 82 & $\mathbf{1 6 8}$ & 30 \\
Albert Reef & 1 & 117 & $\mathbf{1 1 7}$ & 117 \\
Adele Island & 16 & 57 & $\mathbf{5 8}$ & 57 \\
Fraser Island & 0 & 191 & $\mathbf{1 9 7}$ & $\mathbf{1 8 1}$ \\
Beagle Reef & 87 & 86 & $\mathbf{8 6}$ & 86 \\
Irvine \& Bathurst Islands & 41 & 93 & $\mathbf{1 3 3}$ & 46 \\
Mavis Reef & 0 & 42 & $\mathbf{6 9}$ & 28 \\
King \& Conway Islands & 0 & 96 & $\mathbf{9 6}$ & 96 \\
Total & $\mathbf{2 7 3}$ & $\mathbf{2 7}$ & $\mathbf{8 3}$ & 83 \\
\hline
\end{tabular}

Bonaparte Archipelago

$\begin{array}{lllll}\text { Champagny Island } & 0 & 73 & \mathbf{7 3} & 73 \\ \text { Wildcat Reefs } & 66 & 36 & \mathbf{7 7} & 11 \\ \text { Montgomery Reef } & 116 & 120 & \mathbf{1 7 7} & 61 \\ \text { Black Rocks } & 0 & 67 & \mathbf{6 7} & 67 \\ \text { White Island } & 21 & 122 & \mathbf{1 2 6} & 105 \\ \text { De Freycinet Island } & 32 & 84 & \mathbf{8 8} & 56 \\ \text { Hedley Island } & 24 & 83 & \mathbf{9 1} & 67 \\ \text { Colbert Island } & 30 & 44 & \mathbf{6 6} & 36 \\ \text { Woodward Island } & 43 & 43 & \mathbf{7 6} & 33 \\ \text { Robroy Reefs } & 96 & 128 & \mathbf{1 5 5} & 59 \\ \text { Maret Islands } & 34 & 81 & \mathbf{9 9} & 65 \\ \text { Berthier Island } & 34 & 24 & \mathbf{5 6} & 22 \\ \text { Heritage Reef } & 71 & 92 & \mathbf{1 1 7} & 46 \\ \text { Montalivet Islands } & 70 & 123 & \mathbf{1 4 4} & 74 \\ \text { Patricia Island } & 0 & 76 & \mathbf{7 6} & 76\end{array}$




\begin{tabular}{|c|c|c|c|c|}
\hline & Historic & Recent & Total & Recent Additions \\
\hline Jamieson Reef & 44 & 95 & 103 & 59 \\
\hline Condillac Island & 0 & 101 & 101 & 101 \\
\hline Total & 383 & 340 & 511 & 128 \\
\hline \multicolumn{5}{|l|}{ Cassini/Long } \\
\hline Cassini Island & 169 & 225 & 278 & 109 \\
\hline Long Reef & 71 & 189 & 206 & 135 \\
\hline Total & 188 & 270 & 320 & 132 \\
\hline \multicolumn{5}{|l|}{ Mid-Shelf Shoals } \\
\hline Browse Island & 1 & 220 & 220 & 219 \\
\hline Echuca Shoal & 0 & 50 & 50 & 50 \\
\hline Heywood Shoal & 0 & 90 & 90 & 90 \\
\hline Vulcan Shoal & 0 & 78 & 78 & 78 \\
\hline Eugene McDermott Shoal & 0 & 96 & 96 & 96 \\
\hline Total & 1 & 274 & 274 & 273 \\
\hline \multicolumn{5}{|l|}{ Rowley Shoals } \\
\hline Imperieuse Reef & 142 & 330 & 346 & 204 \\
\hline Clerke Reef & 486 & 317 & 559 & 73 \\
\hline Mermaid Reef & 418 & 298 & 471 & 53 \\
\hline Total & 605 & 423 & 685 & 80 \\
\hline \multicolumn{5}{|l|}{ Ashmore/ Cartier/ Hibernia } \\
\hline Ashmore Reef & 791 & 423 & 832 & 41 \\
\hline Hibernia Reef & 345 & 252 & 438 & 93 \\
\hline Total & 886 & 459 & 926 & 40 \\
\hline Kimberley Total & 1470 & 840 & 1529 & 59 \\
\hline
\end{tabular}

TABLE 2 New fish species records from recent Kimberley surveys. Species are additions to the list reported by Moore et al. (2014). New records for Western Australia and Australian waters are indicated.

\begin{tabular}{|c|c|c|c|c|}
\hline Family & Species & Kimberley & $\begin{array}{l}\text { Western } \\
\text { Australia }\end{array}$ & Australia \\
\hline Dasyatidae & Pastinachus ater & + & & \\
\hline Myliobatidae & Aetomylaeus vespertilio & + & & \\
\hline Muraenidae & Echidna delicatulus & + & + & + \\
\hline Clupeidae & Sardinella brachysoma & + & + & \\
\hline Syngnathidae & Campichthys tricarinatus & + & & \\
\hline Syngnathidae & Lissocampus fatiloquus & + & & \\
\hline Scorpaenidae & Parascorpaena aurita & + & & \\
\hline Aploactinidae & Pseudopataecus carnatobarbatus & + & & \\
\hline Plesiopidae & Notograptus gregoryi & + & & \\
\hline Apogonidae & Ostorhinchus wassinki & + & & \\
\hline Malacanthidae & Hoplolatilus starcki & + & + & \\
\hline Carangidae & Alepes vari & + & & \\
\hline
\end{tabular}




\begin{tabular}{|c|c|c|c|c|}
\hline Family & Species & Kimberley & $\begin{array}{l}\text { Western } \\
\text { Australia }\end{array}$ & Australia \\
\hline Carangidae & Carangoides gymnostethus & + & & \\
\hline Carangidae & Decapterus macarellus & + & & \\
\hline Carangidae & Seriolina nigrofasciata & + & & \\
\hline Caesionidae & Pterocaesio chrysozona & + & & \\
\hline Caesionidae & Pterocaesio lativittata & + & + & + \\
\hline Caesionidae & Pterocaesio marri & + & & \\
\hline Haemulidae & Diagramma melanacrum & + & + & + \\
\hline Lethrinidae & Lethrinus amboinensis & + & & \\
\hline Lethrinidae & Lethrinus punctulatus* & + & & \\
\hline Lethrinidae & Lethrinus variegatus & + & & \\
\hline Mullidae & Upeneus asymmetricus & + & & \\
\hline Chaetodontidae & Chaetodon plebeius & + & & \\
\hline Pomacentridae & Neoglyphidodon thoracotaeniatus & + & + & + \\
\hline Labridae & Leptoscarus vaigiensis & + & & \\
\hline Labridae & Scarus fuscocaudalis & + & + & + \\
\hline Labridae & Xenojulis margaritaceus & + & & \\
\hline Pinguipedidae & Parapercis xanthozona & + & & \\
\hline Blenniidae & Blenniella bilitonensis & + & & \\
\hline Gobiidae & Amblyeleotris periophthalmus & + & & \\
\hline Gobiidae & Asterropteryx atripes & + & + & + \\
\hline Gobiidae & Ctenogobiops mitodes & + & & \\
\hline Gobiidae & Eviota cf. fasciola & + & & \\
\hline Gobiidae & Eviota cf. nebulosa & + & & \\
\hline Gobiidae & Eviota cf. nigripinna & + & & \\
\hline Gobiidae & Eviota cf. sebreei & + & & \\
\hline Gobiidae & Fusigobius maximus & + & & \\
\hline Gobiidae & Fusigobius melacron & + & & \\
\hline Gobiidae & Gobiodon axillaris & + & & \\
\hline Gobiidae & Palutrus sp. & + & & \\
\hline Gobiidae & Priolepis inhaca & + & & \\
\hline Gobiidae & Trimma maiandros & + & & \\
\hline Acanthuridae & Acanthurus auranticavus & + & & \\
\hline Acanthuridae & Acanthurus leucocheilus & + & & \\
\hline Acanthuridae & Acanthurus maculiceps & + & + & \\
\hline Acanthuridae & Naso fageni & + & & \\
\hline Acanthuridae & Paracanthurus hepatus & + & + & \\
\hline Scombridae & Katsuwonus pelamis & + & & \\
\hline Scombridae & Thunnus obesus & + & & \\
\hline Monacanthidae & Acreichthys radiatus & + & & \\
\hline Tetraodontidae & Lagocephalus sceleratus & + & & \\
\hline
\end{tabular}

* The true identity of this well-known species remains unresolved but this is the name most widely used. 


\section{DISCUSSION}

The shallow marine reefs of the Kimberley Project Area support an incredible diversity of fishes, akin to the more recognised Great Barrier Reef World Heritage Area (Hoese et al. 2006). This is largely a result of the enormous area of coverage $\left(\sim 476,000 \mathrm{~km}^{2}\right)$, its adjacency to the centre of tropical marine diversity (e.g. Gaither and Rocha 2013) and the diversity of habitats (Richards et al. 2018).

This incredibly rich fauna is variably distributed across the region. General biogeographic patterns among fish communities in the Kimberley region are recognised, with a considerably higher diversity in offshore regions and latitudinal effects in inshore areas (Hutchins 1999; Hutchins 2001; Travers et al. 2012, 2018; Moore et al. 2014). A quantified analysis of such patterns is beyond the scope of the present paper and dataset; however, a biogeographic and ecological analysis of patterns of reef fish diversity and distribution using standardised UVC data from this project is underway (Moore et al. in prep). That said, Table 1 clearly supports the view that offshore fish communities are diverse, relative to inshore, and, notwithstanding differences in survey effort and methods, indicates that variation exists across the inshore areas of the Kimberley.

The recent surveys added a substantial number of new species records to every visited reef, especially inshore. This demonstrates how poorly known the Kimberley fish fauna remains and the importance of continued biodiversity assessments in the region. Admittedly, some of the recent additions are species that were known from the region (e.g. Lethrinus spp.) but not formally captured by previous surveys used in the dataset of Moore et al. (2014) or were known west and east of the Kimberley and assumed to have a continuous distribution (e.g. Campichthys tricarinatus). Prior to these recent surveys most of the inshore reefs had only been sampled by dedicated taxonomists on fewer than five occasions and some only once or not at all (see Moore et al. 2014). Even during recent surveys, certain reefs were only visited once or a few times. Such limited sampling precludes generating meaningful species accumulation curves, but no doubt they would not have neared asymptote for most of the Kimberley reefs and the documented species richness at all reefs will continue to grow steadily with increased sampling effort. One significant contribution from the recent surveys was the first museum-based surveys of five midshelf reefs/shoals (Table 1, Mid-Shelf Shoals), recording 273 species. Other than a recent, important BRUVS-based ecological study across a range of depths and habitats by Moore et al. (2017), these reefs had not previously been surveyed.

The recent surveys also highlight the importance of extractive collection methods to understand the true biodiversity of coral reef fishes. In this study, nearly $30 \%$ of all species were only recorded this way. Over the past few decades, UVC has been used extensively as a tool for assessing reef fish diversity and this is rapidly being replaced by remote sampling methods such as BRUVS (e.g. Moore et al. 2017; Langlois et al. 2018). Such methods clearly have an important role in understanding reef fish ecology, distribution and biogeography, which is why UVC was central to the present study and to previous museum-based biodiversity surveys in the region (Done et al. 1994; Hutchins 1995, 1996, 1997, 1998; Morrison and Hutchins 1997; Moore and Morrison 2009). However, our results again demonstrate that these ecological methods miss many cryptic and pelagic species and, in many cases, cannot discriminate between morphologically similar species, and should not be used on their own to assess the total biodiversity of a region. Cryptobenthic fishes are increasingly being recognised for the significant role they play in ecosystem function (e.g. Goatley et al. 2017; Brandl et al. 2018) yet, without dedicated effort many are impossible to detect without extractive methods (e.g. Ackerman 2000). Assessing total biodiversity requires a variety of approaches, including extractive methods and retention of voucher collections for examination by expert taxonomists. More recently, cryptic species (i.e. morphologically similar, as distinct from behaviourally cryptic) are being identified by an integrative approach using genetics, morphology and other attributes, thus extensive voucher material with associated high-quality tissue for DNA extraction is an essential addition building our understanding of the true diversity of the world. Taxonomic research on Kimberley fishes continues - there are many known new species from the region still to be formally described, and other species complexes that are yet to be resolved. Many of these uncertainties, along with other tentative or dubious records, have been excluded from Appendix 1 until identifications have been resolved or verified. Extensive tissue collections were made during this project to support such taxonomic work.

Other non-collection based data exist for some parts of the Kimberley Project Area (e.g. Kospartov et al. 2006; Travers et al. 2012; Moore et al. 2017; ALA 2019; RLS 2019 and extensive databases held 
by other organisations and individuals). Many of these records are observations made by nontaxonomists that are not supported by available, verifiable vouchers or photographs. While we do not necessarily question the validity of all such records (although in some instances, we do), it is impossible to assess the veracity of these records with the same level of rigour applied to the included museum records and therefore we have not attempted to include them. Furthermore, some of these datasets include habitats other than shallow water reefs, such as soft-bottom or mesophotic. This paper also does not capture the knowledge of the Traditional Custodians, particularly in inshore areas, and we encourage future collaborations to share knowledge. We hope that future endeavours can formally confirm the identifications in these other data sources to expand this list of Kimberley marine fish fauna and fully understand the distributions of all species of fishes across the region. The resolution provided by this dataset is critical for understanding finer scale species distributions, which is central to the successful implementation of effective marine protected areas and sanctuary zones (Pyke and Ehrlich 2010; Moore et al. 2016).

\section{ACKNOWLEDGEMENTS}

The Western Australian Museum and its partner agencies respectfully acknowledge the Traditional Custodians of the Kimberley land and sea country, of Elders past and present, and in particular the Dambimangari and Wunambal Gaambera peoples, for collections made on their sea country. The authors would like to acknowledge project manager Clay Bryce and all our participating colleagues. We acknowledge the Australian Museum, Museum and Art Gallery of the Northern Territory and our colleagues Gerry Allen, Doug Hoese, Barry Hutchins, Helen Larson and Barry Russell whose data contributed substantially to the species list. We thank many colleagues for advice with identifications - Gerry Allen, Tony Gill, Doug Hoese, Barry Hutchins, Hisashi Imamura, Helen Larson, Hiroyuki Motomura, Ted Pietsch, John Pogonoski, Werner Schwarzhans, Bill Smith-Vaniz, Will White and Rick Winterbottom. We also thank Mark Allen for technical support, Kate Dawson for data entry and Peter Morrison, Tony Gill and John Pogonoski for comments that greatly improved the manuscript. This project was funded by Woodside Energy and the Western Australian Museum through the Woodside Collection Project (Kimberley).

\section{REFERENCES}

ABRS (2019). Australian Faunal Directory. Australian Biological Resources Study. Australian Government. Available at: https:/ / biodiversity.org.au/afd/home.

Ackerman, J.L. and Bellwood, D.R. (2000). Reef fish assemblages: A re-evaluation using enclosed rotenone stations. Marine Ecology Progress Series 206: 227-237. DOI: $10.3354 /$ meps206227

ALA (2019). Atlas of Living Australia. Available at: www. ala.org.au.

Allen, G.R., Moore, G.I. and Allen, M.G. (2017). Neopomacentrus aktites, a new species of damselfish (Pisces: Pomacentridae) from Western Australia. Journal of the Ocean Science Foundation 29: 1-10. DOI: 10.5281 /zenodo.1066344

Bortolus, A. (2008). Error cascades in the biological sciences: the unwanted consequences of using bad taxonomy in ecology. Ambio 37: 114-118. DOI: 10.1579/0044-7447(2008)37[114:ecitbs]2.0.co;2

Brandl, S., Goatley, C., Bellwood, D. and Tornabene, L. (2018). The hidden half: ecology and evolution of cryptobenthic fishes on coral reefs: Cryptobenthic reef fishes. Biological Reviews 93: 1846-1873. DOI: 10.1111/ brv.12423

Briggs, J.C. and Bowen, B.W. (2013). Marine shelf habitat: biogeography and evolution. Journal of Biogeography 40: 1023-1035. DOI: $10.2307 / 23463644$

Bryce, C., Bryce, M. and Radford, B. (2018). Project methods and station geomorphology related to a multi-taxon survey (2009-2014) of the Kimberley. Records of the Western Australian Museum Supplement 85. DOI: $10.18195 /$ issn.0313-122x.85.2018.001-043

Caldwell, Z.R., Zgliczynski, B.J., Williams, G.J. and Sandin, S.A. (2016). Reef Fish Survey Techniques: Assessing the Potential for Standardizing Methodologies. PLOS ONE 11(4): e0153066. DOI: 10.1371/journal.pone.0153066

Ceccarelli, D.M., Richards, Z.T., Pratchett, M.S. and Cvitanovic, C. (2011). Rapid increase in coral cover on an isolated coral reef, the Ashmore Reef National Nature Reserve, north-western Australia. Marine and Freshwater Research 62: 1214-1220. DOI: 10.1071/ MF11013

DEC (2009). Protecting the Kimberley. A synthesis of scientific knowledge to support conservation management in the Kimberley region of Western Australia. Department of Environment and Conservation. $46 \mathrm{pp}$.

Done, T.J., Williams, D.M., Speare, P., Turak, E., Davidson, J., DeVantier, L.M., Newman, S.J. and Hutchins, J.B. (1994). Surveys of coral and fish communities at Scott Reef and Rowley Shoals. Unpublished report, Australian Institute of Marine Science.

Fox, J.J. (1998). Reefs and shoals in Australia — Indonesian relations: traditional Indonesian fishermen. In: A. Milner and Quilty, M. Australia in Asia: Episodes. Oxford University Press, Melbourne. pp. 111-139.

Fricke, R., Eschmeyer, W.N. and Laan, V.D. (2019). Eschmeyer's Catalog of Fishes. California Academy of Sciences. Available at: http://researcharchive. calacademy.org/research/ichthyology/catalog/ fishcatmain.asp 
Fromont, J., Bryce, C. and Moore, G. (2012). Kimberley Marine Research Station, Cygnet Bay: notes on the marine fauna. Western Australian Museum. Available at: http:/ / museum.wa.gov.au/research/researchareas/aquatic-zoology/cygnet-bay.

Gaither, M.R. and Rocha, L.A. (2013). Origins of species richness in the Indo-Malay-Philippine biodiversity hotspot: evidence for the centre of overlap hypothesis. Journal of Biogeography 40: 1638-1648. DOI: 10.1111/ jbi.12126

Gilmour, J.P., Smith, L.D., Heyward, A.J., Baird, A.H. and Pratchett, M.S. (2013). Recovery of an isolated coral reef system following severe disturbance. Science 340: 69-71. DOI: $10.1126 /$ science. 1232310

Goatley, C.H.R., Gonzalez-Cabello, A. and Bellwood, D.R. (2017). Small cryptopredators contribute to high predation rates on coral reefs. Coral Reefs 36: 207-212. DOI: $10.1007 / \mathrm{s} 00338-016-1521-1$

Halpern, B.S., Walbridge, S., Selkoe, K.A., Kappel, C.V., Micheli, F., D'Agrosa, C., Bruno, J.F., Casey, K.S., Ebert, C., Fox, H.E., Fujita, R., Heinemann, D., Lenihan, H.S., Madin, E.M.P., Perry, M.T., Selig, E.R., Spalding, M., Steneck, R. and Watson, R. (2008). A Global Map of Human Impact on Marine Ecosystems. Science 319(5865): 948-952. DOI: 10.1126/ science. 1149345

Hoese, D.F., Bray, D.J., Paxton, J.R. and Allen, G.R. (eds) (2006). Fishes. Zoological Catalogue of Australia, Australian Biological Resources Study \& CSIRO Publishing, Collingwood.

Holmes, T.H., Wilson, S.K., Travers, M.J., Langlois, T.J., Evans, R.D., Moore, G.I., Douglas, R.A., Shedrawi, G., Harvey, E.S. and Hickey, K. (2013). A comparison of visual- and stereo-video based fish community assessment methods in tropical and temperate marine waters of Western Australia. Limnology and Oceanography: Methods 11: 337-350. DOI: 10.4319/ lom.2013.11.337

Hutchins, J.B. (1995). Part 11. Fishes. In: F.E. Wells, Hanley, J.R. and Walker, D.I., Survey of the Marine Biota of the Southern Kimberley Islands, Western Australia. Unpublished report, Western Australian Museum. pp. 137-149.

Hutchins, J.B. (1996). Part 9. Fishes. In: D.I. Walker, Wells, F.E. and Hanley, J.R. (eds), Survey of the Marine Biota of the Eastern Kimberley, Western Australia. Unpublished report, Western Australian Museum. pp. $75-84$.

Hutchins, J.B. (1997). Fish. In: C. Bryce, Hutchins, J.B. and Fromont, J. (eds), Restricted Marine Biological Survey of the "Garden Bottom" of Beagle Bay. Unpublished report, Western Australian Museum. pp. 11-17.

Hutchins, J.B. (1998). Survey of the Fishes of Ashmore Reef. Report prepared for Parks Australia North.

Hutchins, J.B. (1999). Biogeography of the nearshore marine fish fauna of the Kimberley, Western Australia. Proceedings of the 5th Indo-Pacific Fish Conference, Nouméa, Society of French Ichthyologists.

Hutchins, J.B. (2001). Biodiversity of shallow reef fish assemblages in Western Australia using a rapid censusing technique. Records of the Western Australian Museum 20: 247-270.
Johnson, J. (2012). Pseudopataecus carnatobarbatus, a new species of velvetfish (Teleostei: Scorpaeniformes: Aploactinidae) from the Kimberley coast of Western Australia. Zootaxa 3245: 54-62.

Johnson, J.W. (2010). Fishes of the Moreton Bay Marine Park and adjacent continental shelf waters, Queensland. Memoirs of the Queensland Museum Nature 54: 299-353.

Johnson, J.W. and Worthington Wilmer, J. (2015). Plectorhinchus caeruleonothus, a new species of sweetlips (Perciformes: Haemulidae) from northern Australia and the resurrection of P. unicolor (Macleay, 1883), species previously confused with $P$. schotaf (Forsskål, 1775). Zootaxa 3985: 491-522. DOI: 10.11646/zootaxa.3985.4.2

Jones, D., Bryce, C., Fromont, J. and Moore, G., (eds) (2017). Marine Biodiversity of the Kimberley 1880s2009. Records of the Western Australian Museum Supplement 84.

Kimberley Land Council. (2019). Indigenous Protected Areas. Available from https://www.klc.org.au/ indigenous-protected-areas/.

Knowlton, N. and Jackson, J. (2008). Shifting baselines, local impacts and global change on coral reef. PLoS Biology 6: 215-220. DOI: 10.1371/journal.pbio.0060054

Kospartov, M., Beger, M., Ceccarelli, D. and Richards, Z. (2006). An assessment of the distribution and abundance of sea cucumbers, trochus, giant clams, coral, fish and invasive marine species at Ashmore Reef National Nature Reserve and Cartier Island Marine Reserve: 2005. Unpublished report for The Department of the Environment and Heritage. UniQuest Pty Ltd.

Langlois, T., Williams, J., Monk, J., Bouchet, P., Currey, L., Goetze, J., Harasti, D., Huveneers, C., Ierodiaconou, D., Malcolm, H. and Whitmarsh, S. (2018). Marine sampling field manual for benthic stereo-BRUVS (Baited Remote Underwater Videos). In: R. Przeslawski and Foster, S. (eds), Field Manuals for Marine Sampling to Monitor Australian Waters, National Environmental Science Programme, Marine Biodiversity Hub. pp. 82-104.

Larson, H., S. Williams, R. and Hammer, M. (2013). An annotated checklist of the fishes of the Northern Territory, Australia. Zootaxa 3696: 1-293. DOI: 10.11646/ zootaxa.3696.1.1

Le Nohaïc, M., Ross, C.L., Cornwall, C.E., Comeau, S., Lowe, R., McCulloch, M.T. and Schoepf, V. (2017). Marine heatwave causes unprecedented regional mass bleaching of thermally resistant corals in northwestern Australia. Scientific Reports 7: 14999. DOI: 10.1038/s41598-017-14794-y

Molony, B.W., Newman, S.J., Joll, L., Lenanton, R.C.J. and Wise, B. (2011). Are Western Australian waters the least productive waters for finfish across two oceans? A review with a focus on finfish resources in the Kimberley region and north coast subregion. Journal of the Royal Society of Western Australia 94: 323-332.

Moore, C.H., Cappo, M., Radford, B. and Heyward, A. (2017). Submerged oceanic shoals of north Western Australia are a major reservoir of marine biodiversity. Coral Reefs 36: 719-734. DOI: 10.1007/s00338-0171564-y 
Moore, C.H., Radford, B., Possingham, H., Heyward, A., Stewart, R., Watts, M., Prescott, J., Newman, S., Harvey, E., Fisher, R., Bryce, C., Lowe, R., Berry, O., Espinosa-Gayosso, A., Spore, E. and Saunders, T. (2016). Improving spatial prioritisation for remote marine regions: optimising biodiversity conservation and sustainable development trade-offs. Scientific Reports 6: 32029.

Moore, G.I. and Morrison, S.M. (2009). Fishes of three North West Shelf atolls off Western Australia: Mermaid (Rowley Shoals), Scott and Seringapatam Reefs. Records of the Western Australian Museum Supplement 77: 221-255. DOI: 10.18195/issn.0313122x.77.2009.221-255

Moore, G.I., Morrison, S.M., Hutchins, J.B., Allen, G.R. and Sampey, A. (2014). Kimberley marine biota. Historical data: fishes. Records of the Western Australian Museum Supplement 84: 161-206. DOI: 10.18195/ issn.0313-122x.84.2014.161-206

Morrison, S.M. and Hutchins, J.B. (1997). Part 8. Fishes. In: D.I. Walker (ed.), Marine Biological Survey of the Central Kimberley Coast, Western Australia. Unpublished Report, Western Australian Museum. pp. 67-76.

Nakamura, J., Russell, B.C., Moore, G.I. and Motomura, H. (2018). Scolopsis meridiana, a new species of monocle bream (Perciformes: Nemipteridae) from northern Australia. Zootaxa 4500: 222-234. DOI: 10.11646/zootaxa.4500.2.4

Nowara, G.B. and Newman, S.J. (1996). The Kimberley Demersal Scalefish Fishery: Extent and nature of the resource and the ability of a trap fishery to exploit it - Part 1: A history of fishing activities in the region. Final Report to the Fisheries Research and Development Corporation (FRDC) on Project No. 94/026.

Pauly, D. (1995). Anecdotes and the shifting baseline syndrome of fisheries. Trends in Ecology and Evolution 10: 430.

Perry, A.L., Low, P.J., Ellis, J.R. and Reynolds, J.D. (2005). Climate change and distribution shifts in marine fishes. Science 308: 1912-1915. DOI: 10.1126/ science. 1111322

Plaisance, L., Caley, M.J., Brainard, R.E. and Knowlton, N. (2011). The Diversity of Coral Reefs: What Are We Missing? PLOS ONE 6(10): e25026. DOI: 10.1371/ journal.pone.0025026

Pyke, G.H. and Ehrlich, P.R. (2010). Biological collections and ecological/environmental research: a review, some observations and a look to the future. Biological Reviews 85: 247-266. DOI: 10.1111/j.1469185X.2009.00098.x

Richards, Z.T., Bryce, M. and Bryce, C. (2018). The composition and structure of shallow benthic reef communities in the Kimberley, north-west Australia. Records of the Western Australian Museum Supplement 85: pp. 75-103: DOI: 10.18195/issn.0313122x.85.2018.075-103
Richards, Z.T., Garcia, R., Moore, G.I., Fromont, J., Kirkendale, L., Bryce, M., Bryce, C., Hara, A., Ritchie, J., Gomez, O., Whisson, C., Allen, M.G. and Wilson, N.G. (2019). A tropical Australian refuge for photosymbiotic benthic fauna. Coral Reefs: DOI: 10.1007/s00338-00019-01809-00335.

RLS. (2019). Reef Life Survey. Available from https:// reeflifesurvey.com

Roberts, C., Stewart, A., Struthers, C., Barker, J. and Kortet, S. (2019). Checklist of the Fishes of New Zealand. Online version 1.1. Museum of New Zealand Te Papa Tongarewa. Available at: https://collections. tepapa.govt.nz/document/10564

Samoilys, M.A. and Carlos, G. (2000). Determining methods of underwater visual census for estimating the abundance of coral reef fishes. Environmental Biology of Fishes 57: 289-304. DOI: 10.1023/A:1007679109359

Smith-Vaniz, W., L. Jelks, H. and Rocha, L. (2006). Relevance of cryptic fishes in biodiversity assessments: A case study at Buck Island Reef National Monument, St. Croix. Bulletin of Marine Science 79: 17-48.

Travers, M.J., Clarke, K.R., Newman, S.J. and Hall, N.G. (2018). To what extents are species richness and abundance of reef fishes along a tropical coast related to latitude and other factors? Continental Shelf Research 167: 99-110. DOI: 10.1016/j.csr.2018.08.006

Travers, M.J., Potter, I.C., Clarke, K.R. and Newman, S.J. (2012). Relationships between latitude and environmental conditions and the species richness, abundance and composition of tropical fish assemblages over soft substrata. Marine Ecology Progress Series 446: 221-241.

Usseglio, P. (2015). Quantifying reef fishes: bias in observational approaches. In: C. Mora (ed.), Ecology of Fishes on Coral Reefs. Cambridge University Press, Cambridge: pp. 270-273. DOI: 10.1017/ CBO9781316105412.035

Vergés, A., Steinberg, P.D., Hay, M.E., Poore, A.G.B., Campbell, A.H., Ballesteros, E., Heck, K.L., Booth, D.J., Coleman, M.A., Feary, D.A., Figueira, W., Langlois, T., Marzinelli, E.M., Mizerek, T., Mumby, P.J., Nakamura, Y., Roughan, M., van Sebille, E., Gupta, A.S., Smale, D.A., Tomas, F., Wernberg, T. and Wilson, S.K. (2014). The tropicalization of temperate marine ecosystems: climate-mediated changes in herbivory and community phase shifts. Proceedings of the Royal Society of London B: Biological Sciences 281(1789): 20140846. DOI: 10.1098/rspb.2014.0846

Wilson, B. (2013). The Biogeography of the Australian North West Shelf: Environmental Change and Life's Response. Elsevier, Burlington, MA.

Wilson, B. (2014). Kimberley marine biota. History and environment. Records of the Western Australian Museum Supplement 84: 1-18. DOI: $10.18195 /$ issn.0313122x.84.2014.001-018 


\section{APPENDIX 1}

Species by site table representing all records of shallow water fishes from the Kimberley used in this dataset. Sites are assembled into Island Groups, approximately arranged by latitude. H refers to a historical record collected pre-2009 (see Moore et al. 2014); R refers to a recent record collected during the 2009-2014 surveys (see Bryce et al. 2018).

An electronic version of this appendix is available to download here:

http://dx.doi.org/10.18195/issn.0313-122x.85.2020.105-115 